\title{
A Study of Educational Reform of Economic Law for Non-law Majors under the Training Mode of Applied Talents
}

\author{
Mo Jianjian \\ Fuzhou University of International Studies and Trade, Fu Jian, Fu Zhou
}

Keywords: Economic law, Non-law major, Teaching, Application-oriented mode.

Abstract: Under the condition of market economy, application-oriented universities and colleges gradually strengthen their legal education in order to achieve their professional training objectives. As the "game rule" of the market economy, the economic law has been set up as a professional basic course or even the core course of some undergraduate economy and management majors in most colleges and universities. However, because of the particularity of Economic law course in non-law majors, its teaching methods is doomed to be different from the teaching of economic law course of law major. In view of the cultivation of applied talents, this paper analyzes the characteristics of the course teaching of non-law major economic law, and aims at the problems in the teaching of non-law major economic law in colleges and universities, contributing to reform the teaching of economic law of non-law majors from the aspects of teaching idea, teaching process and evaluation of teaching results.

Original article, Published date: 2018-06-19

DOI: 10.23977/aetp.2018.21004

ISSN: ISSN 2371-9397 (Print), ISSN 2371-9400 (Online)

https://www.clausiuspress.com/journal/AETP.html 


\section{The characteristics of the course of economic law for non-law majors}

\subsection{The particularity of the subject of teaching}

\subsubsection{The distinctive background of teaching non-law students}

In general, the students of law school are studying the basic courses of jurisprudence, constitutional law, civil law, commercial law and so on, and have some basic theory knowledge of law and the way of thinking of law. Only by this, can they begin to learn the course of economic law. The students who are not law majors build a professional knowledge system based on their own core curriculum. Their thinking mode is based on their own professional knowledge. The different professional background makes the non-law students lack the basic knowledge of legal theory. At the beginning of learning Economic law courses, they would face many problems such as difficulty in entry, difficulty in understanding and difficulty in analysis and so on. In the course of teaching, teachers should also spend a lot of time explaining the basic theory and terms of law, which not only affects the fluency of teaching, but also takes up valuable classroom teaching time, which makes teaching and learning seem more laborious.

\subsubsection{The compound professional knowledge of teaching teachers}

The course of Economic law is rich in teaching content. It involves not only the knowledge of law but also the knowledge of economy and management. This requires that the teacher not only have a solid foundation of legal theory, but also be familiar with the related knowledge of economy and management so as to make a thorough understanding of the law rules and grasp the accuracy of the knowledge points. In particular, when teachers need to explain the latest laws and regulations in the economic field, it is very important for teachers to grasp knowledge accurately.

\subsection{The particularity of teaching setting}

\subsubsection{The particularity of the teaching goal}

In the teaching system of non-law majors, the economic law, mainly from the angle of the socialist economic order, helps students to carry out social activities independently under the guidance of legal thought and scientific spirit and guides them to master the legal basis. The goal of the curriculum is to guide students to respect the Economic law and apply it to daily social practice and carry out specific social activities with the law.

\subsubsection{The difference between the settings of subjects}

The course of economic law of non-law major is a basic course based on the general law course, which is offered in the low grade of non-law major. But the legal common sense of the students is relatively lacking, which means that many students cannot form a clear legal system. This requires 
teachers to carry out teaching in a simple and easy way in the teaching process, paying attention to carrying out general jurisprudence in economic law teaching.

\subsection{The particularity of teaching content}

The teaching content is diverse and pertinent. In China, although the economic law has grown into an independent secondary discipline, its basic theory is not yet mature, and the basic system has not yet been established. The various types of textbooks of economic law published at various levels are different from the arrangement of the system or the selection of the content of the law, which requires the selection of teaching content to be pertinent to meet the needs of the knowledge construction of different professional students and not to adopt a comprehensive teaching method. For example, the accounting law and the audit law are the knowledge that must be learned for the students of the accounting major. But for the students of the international trade major, these are not necessary. Similarly, the Foreign Trade Law is not necessary content that the accounting students must learn. Therefore specific arrangements should be made in accordance with specific circumstances.

\section{Problems in the teaching of economic law for non-law majors}

\subsection{Problems in teaching Ideas}

The value goal of economic law course teaching is to train economic, managerial and applied talents with both refined economy and legal knowledge. Only by making this clear can we adjust our teaching to meet this requirement. However, for the teaching of the economic law course, what we have always paid more attention to is the teaching of theory. In the orientation of the teaching of economic law, we should train the students into research talents in economic law, not the practical talents of economic law. In the view of education, as long as the basic theoretical framework of economic law is instilled to the students, the students can apply the economic law concepts and economic law principles to concrete practical work. However, in fact, there is a process of transformation between the theory of economic law and the specific application of economic law, and our teaching has not been done enough in the aspect of transformation.

\subsection{Problems in the teaching process}

There is the contradiction between students' professional needs and the teaching method of "general theory". Economic law is closely related to economics and management, and the learning of relevant legal knowledge becomes a necessary part of students' learning. The training goal of economics and management majors is to cultivate specialized talents engaged in economic and management work. The course arrangement and design of the specialty are all around the training goal. However, the current teaching is still in the pursuit of comprehensive teaching in the case of limited class hour, which makes the study of economic law disjointed with professional learning. And teachers are often unable to penetrate into the teaching of the knowledge of economic law that students most need to know and master. 
In addition, the economic law is a very practical course. The use of case teaching can stimulate students' interest in learning, enlighten the students to think and shorten the gap between theory and practice, so as to improve the ability of students to solve practical problems. But as a deepening of teaching, case teaching is affected by the mastery of students' basic knowledge. The class hour of economic law courses for non-law majors is limited and the students lack the relevant basic knowledge of law, which attributes to the contradiction between the theoretical teaching and the case teaching which should have been organically combined. The students are not able to understand the basic theoretical knowledge, and the students are not able to analyze and discuss the cases independently.

\subsection{Problems in the evaluation of teaching results}

Non-law majors, such as Accounting, Financial Management, Auditing, and so on, are very practical professional. In the examination, they pay more attention to the students' understanding of books, and they do not inspect the students' practical ability. In the final assessment, there appears a phenomenon that students who do not concentrate on lectures at ordinary times will be able to get high marks in the examination by rote learning of book knowledge. Teaching evaluation is the key link to promote the smooth development of teaching activities. Because of the inaccuracy of teachers' grasp of the content and theory of the teaching of economic law, it has a direct impact on the smooth development of teaching evaluation activities. Under the requirements of the concept of applied talents training, the problem of theory orientation in the teaching of economic law for non-law majors still exists, which makes the teacher cannot effectively evaluate the students' learning around the practice link, and cannot make the students truly realize the problems in the course of economic law practice.

\section{The Mode of Educational Reform of Economic Law for Non-law Majors under the}

\section{Training Mode of Applied Talents}

\subsection{Establishing the teaching idea of deep interest and innovation}

Interest orientation of the students is to stimulate the initiative of the students to learn, to improve their interest in learning, to strengthen the interaction in the classroom, and to emphasize the communication between teachers and students, students and students. On the one hand, it requires teachers to choose vivid and lively teaching methods, abandon the traditional "one - speaker" teaching method, and guide the students to "take the law as an essential part of the ultimate meaning of life". On the other hand, we should gradually reduce the tendency to be academic in the teaching process, and try to restore the economic law back to the social reality.

Innovation orientation is to cultivate students' subjective consciousness and innovative spirit, to explore students' subjective initiative and develop their creativity. To establish this concept, we must realize the following changes: First is to realize the transformation of teaching thinking, that is, changing single thinking into pluralistic thinking. Through the cultivation of students' open thinking, predictive thinking, multivalued thinking and strategic thinking, they can improve their 
acuity, heterosexual, unique and imaginative. Second is to change the concept of law teaching, that is, narrowing the subject teaching into a broad subject teaching, and changing applicability teaching into adaptive teaching. The last one is to realize the transformation of the teaching mode of law, that is, changing the traditional teaching mode into a modern open teaching mode. We should make full use of modern information technology and inspire students' talents respectively according to their different personalities and potentials.

\subsection{Reasonably arranging teaching contents, improving teaching quality and innovating overall teaching methods}

\subsubsection{Making reasonable arrangements for the teaching content}

In terms of teaching content, we can take the textbook of economic law designated by accountants and other examinations as templates, and choose the content according to the actual needs of students. This can be more in line with the actual situation. Students can learn the curriculum of economic law in the school, and participate in the relevant accounting tests, which are more to meet the actual needs of the students. The content of teaching can also be supplemented by relevant knowledge, and the teaching of key contents should be carried out according to the qualification examination.

\subsubsection{Improving the comprehensive quality of teachers}

In the teaching of economic law, teachers should have the accomplishment of law. Economic law has the characteristics of adaptability and application and so on. This requires our teachers to have solid theoretical knowledge and higher practical ability. Teachers should constantly improve their own level, speed up the reform of teaching mode and improve the quality of teaching. Teachers should also understand the examination requirements of the Accounting Qualification Examination, and combine them with the teaching of economic law, so as to improve their teaching ability.

\subsubsection{Reforming teaching methods and emphasizing the cultivation of practical ability}

About the teaching mode, we should change the previous teaching mode. The teaching of economic law pays more attention to the analysis of the case. When choosing the case, we should pay more attention to the method, and the person who participates in it is engaged in the accounting profession so that it can attract the students' more interest.

\subsection{Perfecting the teaching evaluation system}

"Examination is a means of evaluation, aiming at reflecting problems and improving teaching methods." The evaluation of the course reflects the actual effect of the teaching. The traditional evaluation of the course of economic law is based on the requirement of insisting on the "unified test paper and the unified evaluation". The quantitative evaluation is made according to the proportion of the roll surface and the usual performance to a certain proportion. This evaluation mechanism cannot reflect the students' ability of solving problem, and cannot measure the promotion of economic law teaching reform to audit professional training mode. In the assessment, 
we should change the traditional way of assessment, pay attention to the examination of students' comprehensive ability, and examine them in many ways. For example, according to the requirements of the final examination papers, we should adhere to the "the unified proposition, the unified test paper" principle, standardize the scoring standard, and achieve quantitative fairness. The quantification of normal performance is based on students' usual performance, and mainly depends on the detailed quantification of all the factors such as attendance, classroom questions-answering and homework completion. Quantification of practical ability can be carried out by way of mock court. After teaching the content of each chapter, the teacher can select some representative cases, which are played by the students, the judges and the other participants in the litigation. In accordance with the provisions of the civil procedure law, the case is heard in public. In this way, we can assess students' comprehensive ability of organization and coordination, logical analysis and adaptability of court debate.

\section{Conclusion}

In the economic society, we should pay attention to the training of applied talents, and the Economic law occupies a very important position in it. Therefore, the study of Economic law should pay attention to the operation of practical ability, and the school should change the traditional teaching mode so as to adapt to the trend of the development of the times and cultivate professional talents for the society. The teaching of Economic law in the training mode of applied talents must start from the needs of the students, give full play to the instructing role of the teachers, perfect the teaching evaluation system, and pay attention to the related teaching work under the combination of theory and practice.

\section{Acknowledgement}

This research was financially supported by the key course fund of Economic Law of Fuzhou Univer sity of International Studies and Trade (Grant NO. J2016033).

\section{References}

[1] Hu Lili.Study on the Educational Reform of Economic Law for Non-law Majors under the Training Mode of Applied Talents[J].Journal of Hubei University of Economics: Humanities and Social Science Edition.2013(8):169-170.

[2] Yan Wei. Study on the Curriculum Reform of the Economic Law Based on the Training of the Integrated Professional Management Talents[J].2016(31):164.

[3]Bai Xiao. Study on the Educational Reform of Economic Law for Accounting Major under the Training Mode of Applied Talents[J].New Education Era Electronic Magazine (Teacher Edition).2016(12):512.

[4]Xu Xiaoyan. On the Educational Reform of Economic Law for Accounting Major under the Training Mode of Applied Talents[J].Modern Economic Information.2017(25):436. 